\author{
Aleksander URBAŃSKI ${ }^{1}$ \\ Michat GRODECKI ${ }^{2}$ \\ Andrzej KOT $^{3}$
}

\title{
SYMULACJE NUMERYCZNE W ANALIZIE WAŁÓW PRZECIWPOWODZIOWYCH
}

\begin{abstract}
Artykuł przedstawia metodologię numerycznego modelowania najważniejszych dla praktyki inżynierskiej zagadnień oceny bezpieczeństwa wałów przeciwpowodziowych. Z uwagi na zakres czasowy zachodzących zjawisk filtracyjnych problem filtracji musi być rozważany jako nieustalony oraz połączony $\mathrm{z}$ analizą mechaniczną (deformacji i stateczności). Opisane podejście zostało zilustrowane przykładami wyników analiz rzeczywistych wałów. Obliczenia wykonano systemem Metody Elementów Skończonych (MES) ZSoil.PC.
\end{abstract}

Słowa kluczowe: wały przeciwpowodziowe, filtracja nieustalona, stateczność budowli ziemnych, MES, symulacje

\section{Wprowadzenie}

\subsection{Uwagi ogólne}

Renowacja istniejących wałów przeciwpowodziowych lub projektowanie nowych jest tym obszarem działalności inżyniera-hydrotechnika, w którym stosowanie symulacji komputerowych znajduje szerokie zastosowanie. Jest to w pełni uzasadnione zarówno złożonością występujących zjawisk jak i znaczeniem właściwego doboru parametrów projektowych dla bezpieczeństwa i skuteczności inwestycji oraz jej kosztów. Warto w tym miejscu wspomnieć, że aktualne regulacje prawne procesu projektowania hydrotechnicznego, zawarte w Rozporządzeniu [5] oraz w normie EC7 [4] w pełni na to zezwalają.

W okresie ostatnich prawie 20 lat (od pamiętnej powodzi w 1997r.) w Politechnice Krakowskiej wykonano wiele (kilkadziesiąt) analiz wałów przeciwpowodziowych, w toku których opracowano metodykę symulacji komputerowych

\footnotetext{
${ }^{1}$ Autor do korespondencji/corresponding author: Aleksander Urbański, Politechnika Krakowska, Wydział Inżynierii Środowiska, Instytut Geotechniki, aurbansk123@gmail.com

${ }^{2}$ Michał Grodecki, Politechnika Krakowska, Wydział Inżynierii Środowiska, Instytut Geotechniki, mgrode@ pk.edu.pl

3 Andrzej Kot, AQUIN Agata Władysława Rakoczy Kot, andrzejleszekkot@gmail.com
} 
uwzględniającą realistycznie zjawiska filtracji nieustalonej i ich wpływ na stateczność budowli ziemnej. W artykule przedstawia się krótko podstawy teoretyczne, metodykę obliczeń oraz przykłady zastosowań praktycznych symulacji komputerowych zachowania się wałów przy przejściu fali powodziowej. Wykorzystywano przy tym system MES ZSoil.PC ${ }^{4}$. Szerszy opis algorytmów modelowania można znaleźć w pracach [1], [2] i [6].

\subsection{Analiza filtracji nieustalonej i stateczności wału przy przejściu fali powodziowej}

Symulacje numeryczne używane do oceny bezpieczeństwa i skuteczności wałów przeciwpowodziowych powinny w pierwszej kolejności wyznaczać czasoprzestrzenny rozkład pola ciśnień filtracyjnych $p(\mathbf{x}, t)$ (w szczególności powierzchnię swobodną) w celu określenia, czy korpus wału jest nawodniony czy też nie oraz uzyskania zasięgu potencjalnej strefy wysięków. Z drugiej strony rozkład ciśnień filtracyjnych odgrywa zasadniczą rolę w analizie stateczności. Analizowane są również czasoprzestrzenne rozkłady prędkości filtracji $\mathbf{q}(\mathbf{x}, t)$, powiązane z rozkładem ciśnień i współczynnikiem filtracji na podstawie zmodyfikowanego przez van Genuchtena [3] prawa Darcy. Możliwe staje się określenie ilości wody filtrującej przez wał i jego podłoże w czasie wezbrania, a tym samym stwierdzenie skuteczności zastosowanych rozwiązań konstrukcyjnych (różnego rodzaju przesłony filtracyjne, ekrany z geo-syntetyków, rdzenie i warstwy z gruntów słaboprzepuszczalnych). Ponadto umożliwia to ocenę bezpieczeństwa wału pod względem zagrożenia stanem granicznym HYD wg EC7 [4] (sufozja).

W przypadku, gdy geometria wału oraz parametry gruntu nie zmieniają się wzdłuż wału, model numeryczny buduje się z założeniem dwuwymiarowego przepływu w płaszczyźnie przekroju oraz płaskiego stanu odkształceń. Analiza stateczności wałów przeciwpowodziowych musi uwzględniać obecność wody nie tylko jako obciążenia zewnętrznego, lecz również jako siły masowej, powstającej w wyniku gradientu ciśnień filtracyjnych działających na szkielet gruntowy. Nie uwzględnienie tego zjawiska może prowadzić do znacznego przeszacowania współczynnika stateczności wału. Często nie jest możliwe określenie z góry, w którym momencie wezbrania ciśnienia filtracyjne będą wywierać najbardziej niekorzystny wpływ na stateczność wału.

\footnotetext{
${ }^{4}$ ZSoil.PC jest systemem nieliniowej analizy MES ogólnego przeznaczenia (statyka i dynamika ośrodka jedno- i dwufazowego, dyfuzja ciepła i wilgoci, filtracja), ukierunkowanym na geotechnikę, hydrotechnikę i inżynierię lądowa. Został opracowany na Politechnice Federalnej (EPFL) w Lozannie (Szwajcaria) i w firmie ZACE Services Ltd., przez zespół działający pod kierownictwem prof. T. Zimmermanna i prof. A.Trutego (PK). Prof. A.Urbański uczestniczył w tworzeniu systemu ZSoil.PC od 1993 roku. Szczegółowe informacje o systemie ZSoil można znaleźć na stronie: www.zace.com
} 
Danymi do oceny bezpieczeństwa i skuteczności działania wałów przeciwpowodziowych są:

- hydrogram piętrzenia prognozowanej fali powodziowej; powstaje on w wyniku analizy hydrologicznej zlewni i hydraulicznej w danym przekroju rzeki. Można go też utworzyć na podstawie przebiegu dotychczasowych powodzi. Poziom piętrzenia wody przez wały przeciwpowodziowe ulega w okresie wezbrania szybkim zmianom. Czas piętrzenia wynosi od kilku godzin w przypadku potoków górskich do kilku tygodni w rzekach nizinnych. Należy zauważyć, iż czas zachodzenia zjawisk filtracyjnych (np. nasycania wału lub spływu) jest na ogół tego samego rzędu co czas trwania wezbrania, co sprawia że analizy bazujące wyłącznie na filtracji ustalonej nie odpowiadają naturze rozpatrywanego zjawiska, szczególnie w rejonach dorzeczy górnej Wisły i Odry.

- parametry filtracyjne i wytrzymałościowe oraz morfologia układu warstw gruntu w podłożu i w korpusie wału; poprawne rozpoznanie geometrii (geodezyjne i geofizyczne) i parametrów (badania in-situ i laboratoryjne) gruntu w korpusie i podłożu wału musi poprzedzać analizę numeryczną filtracji i stateczności. W przypadku ich niepewności bądź niekompletności, co niestety zdarza się dość często, szczególnie kiedy wykonujący badania nie ma świadomości jakie parametry będą użyteczne lub niezbędne dla celów analizy, jedynym sposobem jest wykonanie studium parametrycznego, zakładającego zmienność parametrów w pewnych granicach.

Minimalny zbiór danych obejmuje dla każdej wyróżnionej strefy materiałowej w wale i jego podłożu następujące parametry:

- współczynnik filtracji $k[\mathrm{~m} /$ doba]. Jego znajomość jest niezbędna przy określaniu ilości wody filtrującej przez wał i jego podłoże,

- porowatość $n[-]$ (lub wskaźnik porowatości $e[-]$ ). Parametr ten jest niezbędny do opisu zjawisk w przebiegu filtracji nieustalonej,

$-\gamma_{\mathrm{d}}\left[\mathrm{kN} / \mathrm{m}^{3}\right]$ ciężar objętościowy gruntu suchego,

- $c^{\prime}[\mathrm{kPa}]-$ efektywna kohezja, $\phi^{\prime}\left[{ }^{\circ}\right]$ efektywny kąt tarcia wewnętrznego.

Parametry wytrzymałościowe w modelu Mohra-Coulomba muszą być badane i podawane jako efektywne, ponieważ grunt jest traktowany jako ośrodek dwu-fazowy, z obowiązującym prawem dekompozycji naprężeń TherzagiegoBishopa. Wynika stąd uwzględnienie gradientu ciśnienia porowego $p$ jako dodatkowej siły objętościowej w równaniach równowagi dla naprężeń efektywnych w szkielecie gruntowym $\sigma_{i j}$, gdzie Sjest stopniem wilgotności, a $\mathbf{b}=\left[b_{i}\right]$ ciężarem objętościowym gruntu nawodnionego:

$$
\sigma_{i j, j}^{\prime}+\left(\delta_{i j} S \cdot p\right),_{j}+b_{i}=0
$$

Zastosowany model filtracji nieustalonej bazuje na równaniu Richardsa: 
$\operatorname{div} \mathbf{q}-n \frac{d S}{d p} \cdot \dot{p}=0$

W zastosowanej teorii (za van Genuchtenem [3]) wprowadza się zależność pomiędzy ciśnieniem $p>0$ (ssaniem) w strefie niepełnego nasycenia a stopniem wilgotności $S$ :

$$
S=S(p)=S_{r}+\frac{1-S_{r}}{\left[1+\left(\alpha p / \gamma_{w}\right)^{2}\right]^{0.5}}, \quad p>0
$$

gdzie: $S_{r}$ - stopień wilgotności przy wilgotności minimalnej, $\gamma_{w}$-ciężar objętościowy cieczy, $\alpha-\left[\mathrm{m}^{-1}\right]$ parametr opisujący przejście pomiędzy strefą pełnego nawodnienia a strefą o wilgotności minimalnej. Duża wartość $\alpha$ odpowiada bardziej gwałtownemu przejściu (grunty niespoiste), mała $(\alpha<1.0)$ wydłuża strefę przejściową, (grunty spoiste). Modyfikacji ulega także prawo Darcy'ego, dla strefy niepełnego nasycenia $(p>0,0<S<1)$ :

$$
\mathbf{q}=-k \cdot k_{r}(S(p)) \operatorname{grad}\left(-p / \gamma_{w}+z\right), k_{r}(S)=\frac{\left(S-S_{r}\right)^{3}}{\left(1-S_{r}\right)^{3}}
$$

gdzie $k$ jest współczynnikiem filtracji, a $z$-potencjałem sił ciężkości. Powierzchnia swobodna (krzywa filtracji), na której $p(\mathbf{x}, t)=0$, jest w każdym kroku czasowym analizy znajdowana automatycznie. Używane są także elementy przełączające warunek brzegowy, w zależności od stanu ciśnień na brzegu. W każdym kroku czasowym analizy, wynikającym ze schematu różnicowego całkowania w dziedzinie czasu, rozwiązywany jest nieliniowy układ równań, gdzie poszukiwane jest pole ciśnień $p$ dyskretyzowane elementami skończonymi.

Wyniki analizy filtracji nieustalonej obejmują: rozkład ciśnień porowych w formie map, prędkości filtracji jako wektory, mapy lub rozkłady wzdłuż zadanych linii i ich sumy (przepływy). Uzyskane w dowolnej chwili $t$ pole ciśnień $p$ może być przekazywane automatycznie do analizy stateczności metodą redukcji c-fi [6] (ośrodek sprężysto-plastyczny, model Mohra-Coulomba).Wynikiem analizy stateczności są:

- współczynnik stateczności, odpowiadający współczynnikowi bezpieczeństwa, określanemu w [4] w zależności od klasy budowli hydrotechnicznej,

- postać utraty stateczności (mechanizm zniszczenia) oraz kształt powierzchni poślizgu.

Przebieg deformacji wału w czasie może być również analizowany, lecz nie ma on większego znaczenia praktycznego. 


\section{Przykłady zastosowania praktycznego}

\subsection{Wał zbudowany $z$ gruntów sypkich, posadowiony na uwarstwionym podłożu}

Poniżej przedstawia się wyniki analiz stanu istniejącego wału zbudowanego z pospółki o $\mathrm{ID}=0.79$, posadowionego na uwarstwionym podłożu (na zalegających na przemian warstwach gruntów sypkich i słabych gruntów spoistych). Uzyskane wyniki analiz filtracji (rozkład ciśnień i prędkości filtracji w fazie kulminacyjnej wezbrania) przedstawia Rys. 1.
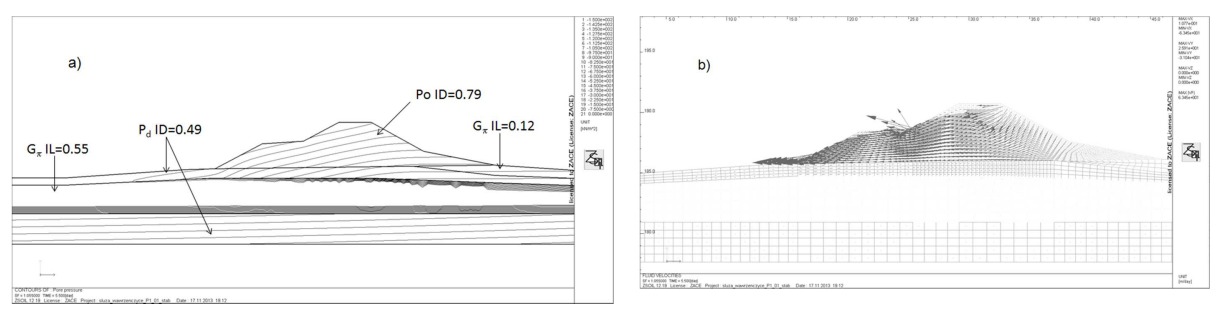

Rys. 1. Rozkład ciśnień (a) i prędkości filtracji (b) w fazie kulminacyjnej wezbrania - wał z gruntów sypkich posadowiony na uwarstwionym podłożu

Fig. 1. Pore pressure (a) and flow velocities (b) distribution during culmination of the flood - dike made from non-cohesive soil, founded on layered subsoil

Obecność w korpusie wału i jego podłożu gruntów sypkich o wysokim współczynniku filtracji prowadzi do powstania znacznych wycieków, wał nie spełnia wymogów szczelności (Rys 2).

Obserwowane wysokie położenie krzywej filtracji stwarza zagrożenie dla stateczności wału. Uzyskane wartości współczynnika stateczności SF wynoszą: przy braku piętrzenia 1.74, przy pełnym piętrzeniu 1.05, w fazie opadającej 1.32 tak więc wał nie spełnia wymogów stateczności. Należy zauważyć, iż głównym czynnikiem negatywnie wpływającym na stateczność wału jest rozkład ciśnień filtracyjnych. Rys. 3 przedstawia charakterystyczne postacie utraty stateczności, w zależności od fazy wezbrania. Zwraca uwagę zmiana mechanizmu zniszczenia w trakcie przejścia fali powodziowej.

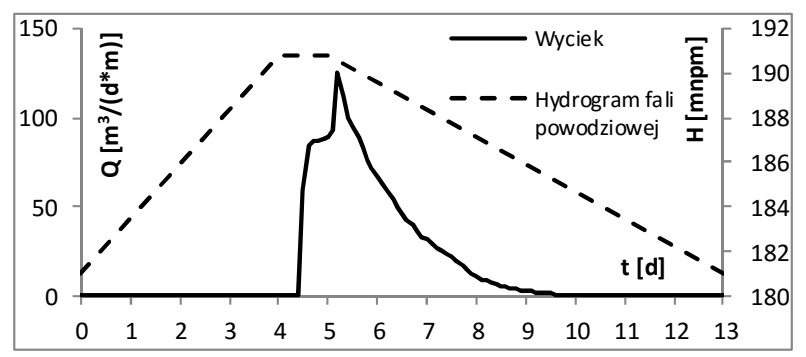

Rys. 2. Wycieki przez wał - wał z gruntów sypkich posadowiony na uwarstwionym podłożu

Fig. 2. Leakage through the dike - embankment made from non-cohesive soil, founded on layered subsoil 

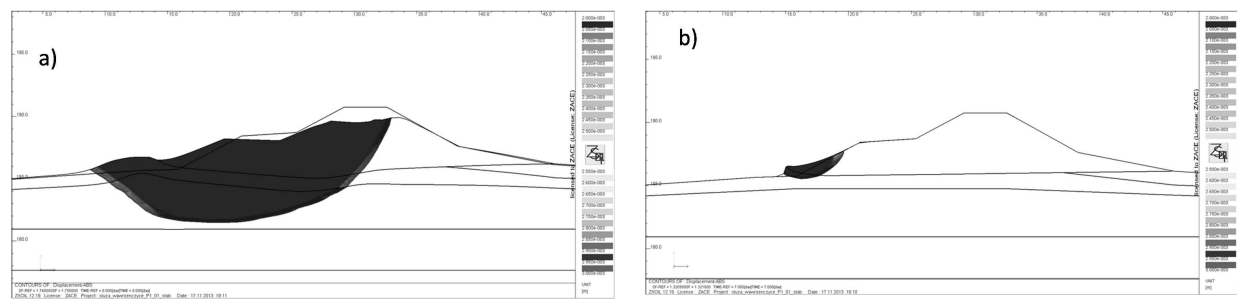

Rys. 3. Mechanizm zniszczenia (powierzchnia poślizgu) a) przy braku piętrzenia b) przy pełnym piętrzeniu i w fazie opadającej - wał z gruntów sypkich posadowiony na uwarstwionym podłożu

Fig. 3. Failure mode (sliding surface) a) in the absence of damming b) during culmination and lowering phase of the flood - embankment made from non-cohesive soil, founded on layered subsoil

\subsection{Nadbudowywany wał, posadowiony na słabonośnym podłożu}

Poniżej przedstawiono wyniki analiz wału nadbudowywanego z powodu niedostatecznej wysokości (projektant - mgr inż. Andrzej Kot). Początkowo planowano wykonać nadbudowę w postaci nasypu ze skały płonnej po stronie odwodnej (wariant wyjściowy). Przeprowadzone symulacje numeryczne wykazały, iż rozwiązanie takie pozwala zapewnić szczelność wału (brak wycieków, Rys. 4) .
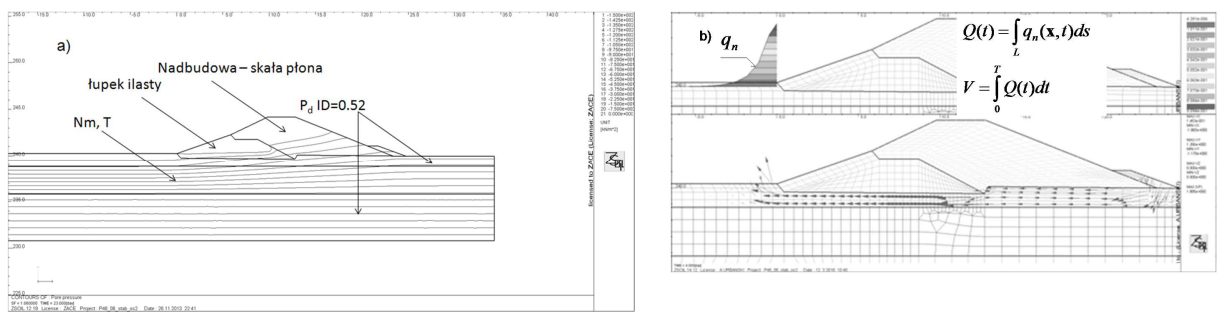

Rys. 4. Rozkład ciśnień (a) i prędkości filtracji (b) w fazie kulminacyjnej wezbrania - wał nadbudowywany skałą płoną posadowiony na słabym podłożu

Fig. 4. Pore pressure (a) and flow distribution (b) during culmination of the flood - embankment enlarged with use of gangue, founded on weak subsoil

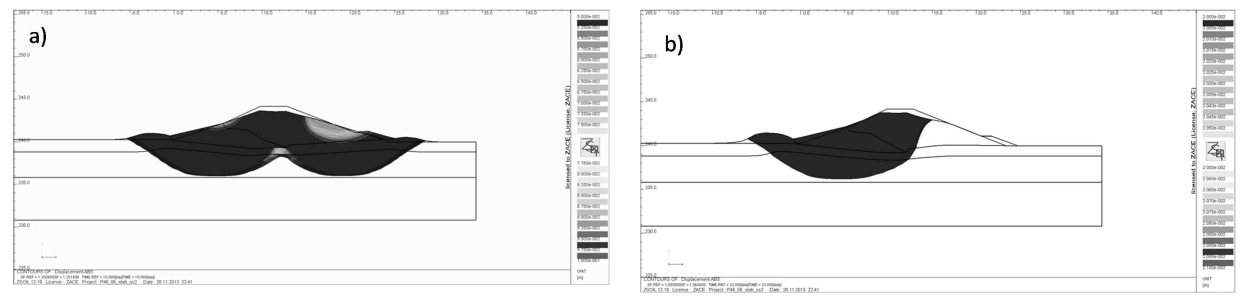

Rys. 5. Mechanizm zniszczenia (powierzchnia poślizgu) a) przy braku piętrzenia i w fazie opadającej b) przy pełnym piętrzeniu - wał nadbudowywany skałą płoną posadowiony na słabym podłożu

Fig. 5. Failure mode (sliding surface) a) in the absence of damming and during culmination b) during lowering phase of the flood - embankment enlarged with use of gangue, founded on weak subsoil 
Analiza wykazała, iż rozwiązanie to nie spełnia wymogów stateczności z uwagi na obecność słabej warstwy gruntów organicznych w podłożu (uzyskano współczynniki stateczności: przy braku piętrzenia 1.25 , przy pełnym piętrzeniu 1.07, w fazie opadającej 1.18 - Rys. 5).

$\mathrm{Z}$ uwagi na stwierdzony znaczny niedobór stateczności wariantu wyjściowego wału zdecydowano się na zastosowanie zabudowy bulwarowej, z wykorzystaniem ścianki szczelnej. Dla zapewnienie stateczności skarpy odpowietrznej niezbędne okazało się zastosowanie niewielkiego nasypu dociążającego. Ostatecznie uzyskano wał szczelny (wycieki do $0.1 \mathrm{~m}^{3} / \mathrm{d} / \mathrm{m}$, Rys. 6) i stateczny (współczynniki stateczności przy braku piętrzenia 1.46, przy pełnym piętrzeniu 1.76, w fazie opadającej 1.49 - Rys. 7).
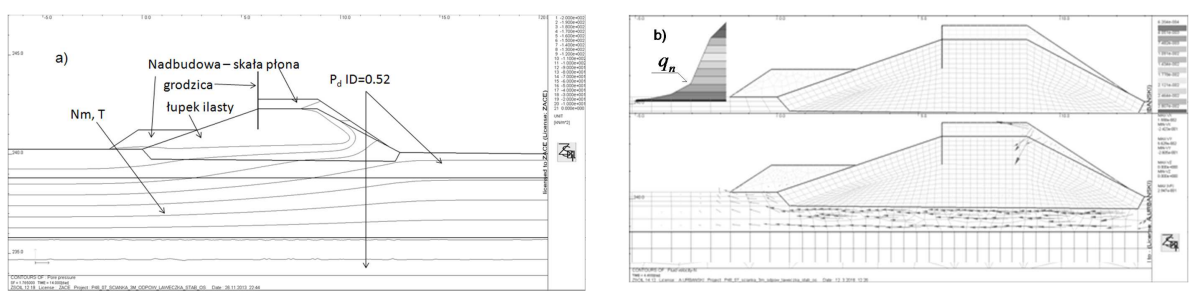

Rys. 6. Rozkład ciśnień (a) i prędkości filtracji (b) w fazie kulminacyjnej wezbrania - wał z zabudową bulwarową posadowiony na słabym podłożu

Fig. 6. Pore pressure (a) and flow (b) distribution during culmination of the flood - embankment with boulevards, founded on weak subsoil
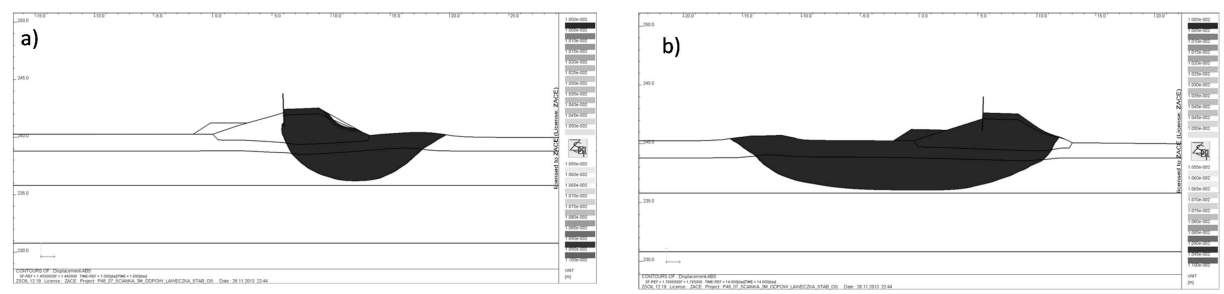

Rys. 7. Mechanizm zniszczenia (powierzchnia poślizgu) a) przy braku piętrzenia i w fazie opadającej b) przy pełnym piętrzeniu- wał z zabudową bulwarową posadowiony na słabym podłożu

Fig. 7. Failure mode (sliding surface) a) in the absence of damming and during culmination b) during lowering phase of the flood - embankment with boulevards, founded on weak subsoil

Rozwiązanie z zabudową bulwarową zostało zaakceptowane do realizacji i wykonane przez firmę Przedsiębiorstwo Budownictwa Wodno-Inżynieryjnego w Krakowie Sp. z o.o w roku 2014, na długości około 225 m. Roboty polegały na nadbudowie oraz poszerzeniu istniejącej grobli poprzez usypanie warstw gruntu o miąższości ok.0,3-0,5m. Każda warstwa, przed usypaniem następnej, została zagęszczona do wymaganego wskaźnika zagęszczenia tj. $I_{s}$ min.= 0,92. Do nadbudowy grobli wykorzystano skałę płonną z kopalni Silesia znajdującą szerokie zastosowanie przy tego typu inwestycjach. 


\section{Wnioski końcowe}

Przedstawiona w niniejszej pracy metodologia prowadzenia symulacji numerycznych pracy wałów przeciwpowodziowych w trakcie wezbrania jest skutecznym narzędziem wspomagającym pracę projektanta-hydrotechnika, pozwalającym na racjonalne podejmowanie decyzji projektowych poprzez realną prognozę zachowania się wału w warunkach powodziowych.

\section{Literatura}

[1] Urbański A., Grodecki M. : FE approach to coupled transient flow and stability analysis of antiflood embankments, Proceedings of the third international conference on advances of computer methods in geotechnical and geoenvironmental engineering Moskwa2000, A.A. Balkema, Rotterdam, Holandia 2000.

[2] Urbański A., Truty A., Grodecki M. : Modelowanie numeryczne nieustalonej filtracji i stateczności wałów przeciwpowodziowych, Materiały Pokonferencyjne IX Konferencji Technicznej Kontroli Zapór Rytro 29-31.05.2001, IMGW 2001.

[3] van Genuchten M.Th.: A closed form equation for predicting the hydraulic conductivity of unsaturated soils, American Society of Soil Sciences, 1980.

[4] Eurokod 7 PN-EN 1997-1 Projektowanie Geotechniczne. Część 1: Zasady ogólne.

[5] Rozporządzenie Ministra Środowiska z dnia 20 kwietnia 2007 r. w sprawie warunków technicznych, jakim powinny odpowiadać budowle hydrotechniczne i ich usytuowanie, Dz. U. 2007 nr 86 poz. 579.

[6] Z_Soil.PC, Theoretical Manual, ZACE Services Ltd., Lozanna 2000.

\section{NUMERICAL SIMULATIONS IN THE ANALYSIS OF ANTI-FLOOD DIKES}

\section{S u m m a r y}

The paper presents a FE - based methodology of numerical modeling of the most important aspects of assessing safety and serviceability of anti-flood dikes. In particular, due to the time scale of undergoing processes, pore fluid flow must be formulated as a non-steadystate problem, and coupled with mechanical deformation and stability analysis. Examples, illustrating the effectiveness of the proposed approach on practical cases, performed with the software system ZSoil.PC, are shown.

Keywords: anti-flood dikes, transient flow, stability of earth structures, FEM, simulations

Przestano do redakcji: 07.06.2016 $r$.

Przyjęto do druku: 30.06.2016 r.

DOI: $10.7862 / \mathrm{rb} .2016 .59$ 